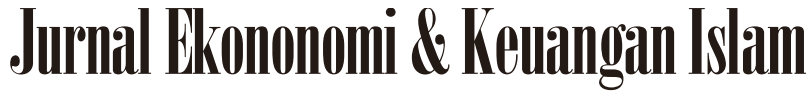

\author{
Available at http://journal.uii.ac.id/index.php/jeki
}

\section{Market performance of sharia-compliant companies in Indonesia: relevance of earnings-management, leverage, and corporate}

\author{
Yunice Karina Tumewang \\ Durham University \\ e-mail: yuni.karina@gmail.com
}

\section{Keywords:}

Bank Umum Syariah, ROA,CAR, Portofolio Akad Bagi Hasil, Inflasi, Pertumbuhan PDB, Akad Qardh dan ZIS

DOI:

10.20885/JEKI.vol3.iss1.art3

\begin{abstract}
This study aims to explore the factors that influence the Islamic bank profitability. The profitability rate or Return on Asset (ROA) is utilized as dependent variable whereas internal financial factor (financial ratio indicator) and external factor (economic indicator) are adopted as independent variable. This study focus on social funds such as qard and ZIS contract. This study applies qualitative description with using time series data from March 2010 to September 2014. Moreover, Panel regression model is employed, MWD test and classical assumption test. This analysis finds that, firstly, financial ration and CAR has positive and not significant relationship although equity based financing has significant and positive relationship then in economic indicator results GDP growth and inflation has positively not significant. Furthermore, social funds indicator such in qard contract has positive and significant relationship to ROA or profitability rate. However, the second regression result that utilizes ZIS variable finds that all variables do not have significant relationship excluding GDP growth.
\end{abstract}

\begin{abstract}
Abstrak
Penelitian ini bertujuan untuk mengetahui faktor apa saja yang dapat mempengaruhi profitabilitas Bank Umum Syariah. Tingkat profitabilitas atau Return On Asset (ROA) digunakan sebagai variabel dependen serta variabel independen yaitu faktor internal (indikator rasio keuangan) dan faktor eksternal (indikator ekonomi). Pada penelitian ini berfokus pada dana sosial seperti akad qardh dan zis. Bentuk penelitian deskripsi kuantitatif ini menggunakan data time series pada priode maret 2010 - September 2014. Sedangkan analisis data yang digunakan yaitu Model regresi data panel, uji MWD dan uji asumsi klasik. Pada hasil regresi pertama diketahui hubungan indikator rasio keuangan seperti CAR berhubungan positif tidak signifikan namun pada portofolio pembiayaan bagi hasil berhubungan positif signifikan lalu pada indikator ekonomi diketahui indikator pertumbuhan PDB dan Inflasi positif tidak signifikan. Kemudian, indikator dana sosial pada akad qardh positif signifikan terhadap ROA atau profitabilitas. Sedangkan pada hasil regresi kedua yang menggunakan variabel ZIS, terdapat hasil bahwa seluruh variabel tidak berpengaruh signifikan kecuali variabel pertumbuhan PDB berpengaruh signifikan.
\end{abstract}

\section{Introduction}

Currently, Sharia institutions has been expanding rapidly, supported by a conducive environment that is renowned for continuous product innovation, a diversity of financial institutions from across the world, a broad range of innovative Islamic investment instruments, a comprehensive financial infrastructure and adopted global regulatory and legal best practices (Choong et al, 2012).Although basically, the goal of the company is just to prosper the owner. One alternative way to achieve the company's prosperity is through maximizing stock price in order to obtain capital gains. Stock market prices are determined by market mechanisms, whichare the demand and supply of the stock in capital market. The increase of investor's interest to have stocks is influenced by the quality or value of the stock in capital market. The level stock value (high or low) actually reflect the company's financial performance. If a company has good financial performance, investors will do the investment, because it would make benefits (Susanto,2010).

Performance evaluation is a method of measuring a company's achievement based on the targets set earlier. It is a part of control measures that can help company to improve its future performance while identifying the deficiencies of its operation throughout the financial year. To have a sound and appropriate performance measurement system is utmost essential especially in today's borderless world in order to remain competitive and financially strong (Ibrahim et al, 2004). Martani, et al. (2009) found no clear evidence that Shariah stocks perform below the conventional stocks. The chance for Shariah investors to gain maximum possible return while at the same time being socially and ethically concerned about their investment is still possible yet debatable. 
The major concern of the Islamic Capital Market (ICM) is ideally characterized by the absence of interest based transactions, doubtful transactions, and trading of shares in companies that deal in activities or items that are unlawful under Islamic (Sharia) law (Alhabshi, 1994). A reevaluation of the listed share will be held every six months, once in January and again in July. However, some non-permissible activities well-known exist in the Sharia-compliant companies are earnings management, leverage, and no fully Islamic disclosure.

In this study, the researcher used only Jakarta Islamic Index as the indicator to show the performance/movement of the top 30 Shariah stock price listed in the Indonesia Stock Exchange. The Jakarta Islamic Index (JII) is a stock market index established on July 3, 2000 on the Indonesia Stock Exchange (IDX) to help facilitate the trading of public companies according to Shariah business code. Islamic law prohibits a company from involving itself in activities related to gambling, speculation, and traditional banking and financing. The JII may not list equities that produce or distribute food, drink, or morally harmful items that stand in contradiction with Islamic values.Considerations for the JII must meet procedural standards as well as performance requirements, such as: a) The share must be listed on the exchange for at least three months prior to application. b) The company's annual or mid-year financial report must have an Obligation Asset ratio of no more than $90 \%$. c) Rank in the top 60 shares based on the previous year's average Market Capitalization. d) Rank in the top 30 shares based on the previous year's average liquidity in the regular market.

Earnings management is said to be a "reasonable and legal management decision making and reporting, intended to achieve and disclose stable and predictable financial results" (Rahman et al. 2013). Most people are aware of the fact that companies earnings are their "net income" or "net profit". A company's earning is believed to be the most important item in the financial statements. It is what most analysts use when analyzing a company's performance and prospective potential. On top of this, the expected value of a company's share price is the present value of all its future earnings, and therefore the value of a company is closely related to the increase or decrease in the earnings. According to Statement of Financial Accounting Concept (SFAC) No.1, earning information is a major concern for assessing the performance or management accountability. Earning information also helps the owner or other parties in assessing the company's earning power in the future. Earning information often becomes the target of engineering from opportunist management action to maximize the management satisfaction, but it can be detrimental for the stockholder or investor (Adiwitarsa, 2011). Indriyani (2010) stated that opportunist management action is conducted by selecting the certain accounting policies, so that profits can be adjusted, increased or reduced in accordance with the management will. This practice is also called as earning management.

Meanwhile, as known from corporate finance theory (Hillier et al., 2008), one of the most common problems of the majority of the firms faces is raising cash for required capital expenditures. The universal goal of any corporation is increasing value and the latter standing for the amount of cash going to firm's investors. Proportions of debt in capital structure depend on the way a company distributes its cash between shareholders and creditors. And in turn, the value of the company depends on this distribution. Back in 1958, Modigliani and Miller presented a theoretical perspective, stating that origins of financing do not matter in perfect capital markets. However, this is not applicable in the real world, and it would be fair to ask what proportions of debt are the best for any given firm with respect to its value.

On the other side, information and incentive problems impede the efficient allocation of resources in a capital market economy. Disclosure and the institutions created to facilitate credible disclosure between managers and investors play an important role in mitigating these problems (Paul et al, 2001). The previous research conducted by Ibrahim (2004) examines how well the organization is disclosing the information that might be useful to the stakeholders by using Islamic disclosure index. All the items chosen are supported by the literature from previous reearch. This index can be further segregated into three major indicators, namely Shariah compliance indicator, corporate governance indicator, and social/environment indicator. This study only focuses on the Shariah compliance indicator.

The other previous research conducted by Isa et al (2013) examines the Shariah compliance indicator by looking at the level of earnings management and leverage. Becasue when Shariah-compliant companies comply with the Shariah principles, they are expected not to involve in nonpermissible activities which has indication of "riba" (interest) and "gharar" (uncertainty). However, some non-permissible activities well-known exist in the Shariah-compliant companies which are earnings management and leverage, as proven by the previous research.

This research combines and integrates the two research conducted by Ibrahim (2004) and Isa et al (2013). This research analyzes the market performance in Shariah-Compliant Companies listed in Jakarta Islamic Index (JII) in 2010-2013. Therefore, in this study, the researcher conduct a research under the title "Market Performance of Shariah-Compliant Companies in Indonesia: The Relevance of Earnings Management, Leverage, and Corporate Disclosure". 


\section{Research Method}

The population of this research is Sharia-compliant companies that are listed in Jakarta Islamic Index (JII). Sample taken in this research is using purposive sampling. The criteria that researcher uses are : Shariacompliant companies which ever listed in Jakarta Islamic Index in 2010-2013, Sharia-compliant companies which issue their annualreport. Sharia-Compliant Companies which did not have good data completeness of firm value, earnings management, leverage ratio, and disclosure. From the criteria, researcher found 136 Shariacompliant companies that can be used as research sample.

The researcher formulated Null ypotheses (Ho) and Alternative Hypotheses (Ha) which must be tested to prove whether the hypotheses were rejected or accepted. There are criteria of testing by T-test, in this research those criteria are divided into two criteria, as follow:

\section{Hypothesis I}

$\mathrm{Ho}_{1}: \beta_{1} \leq 0$ there is no positive impact of earnings management on the market performance

$\mathrm{Ha}_{1}: \beta_{1}>0$ there is positive impact of earnings management on the market performance

\section{Hypothesis 2}

$\mathrm{Ho}_{2}: \beta_{2} \geq 0$ there is no negative impact of leverage ratio on the market performance

$\mathrm{Ho}_{2}: \beta_{2}<0$ there is negative impact of leverage ratio on the market performance

\section{Hypothesis 3}

$\mathrm{Ho}_{3}: \beta_{3} \leq 0$ there is no positive impact of corporate disclosure on the market performance

$\mathrm{Ho}_{3}: \beta_{3}>0$ there is positive impact of corporate disclosure on the market performance

\section{Data Analysis Technique}

For testing hypothesis 1, 2, and 3, this study uses a statistical method of multiple linear regression with models:

$$
M P_{i t}=\alpha+\beta_{1} E M_{i t}+\beta_{2} L R_{i t}+\beta_{3} C D_{i t}+S I Z E+A u d+\varepsilon
$$

$M P_{i t}$ is market performance of company $i$ in year $t . E M_{i t}$ is earnings management of company $i$ in year $t . L R_{i t}$ is leverage ratio of company $i$ in year $t . C D_{i t}$ is corporate disclosure of company $i$ in year $t$. SIZE is the natural logarithm of total assets and Aud to address the dummyvariable. $\varepsilon$ is describe the error term

Dependent variable used is market performance. Independent variables in this research are earnings management, leverage, and corporate disclosure. This study engaged the Tobin's Q ratio in determining the firm's value of the researched firms. This was an option measure to find out market performance. The modified version of the Tobin Q ratio which was implemented by Zunaidah et al. (2008).

$$
\text { Tobin } Q=\frac{M V E+T D E B T}{T A S S T+T D E B T}
$$

Where MVE is Market value of equity. TDEBT (total debt) is the book value of short-term liabilities net of short term assets, plus book value of long-term debt. TASST (total asset) is the book value of total assets.

The independent variables used in this reasearch is market performance, Earnings Management using the abnormal residual cash flow from operation to assets ratio as its proxy. To measure the leverage variable by comparing debt to total assets ratio. Corporate Disclosure is to measure how far the Islamic companies have complied their corporate disclosure with the principles laid down in AAOIFI, this study used Shariah compliance indicator and Corporate Governance Indicator of Islamicity disclosure index.

Here is the Shariah compliance indicator of corporate disclosure based on AAOIFI standards: 1) Shariah Supervisory Board (The appointment of SSB, the report of SSB, Identification the actual activity conducted, The SSB members' background (Name, Educational background, Experiences)), 2) The Vision, mission and objectives, 3) Financial Statement (Identification of Islamic investment, Identification of nonIslamic investment, Identification of Islamic revenue, Identification of non-Islamic revenue, Provide the statement of sources and uses of funds in Zakat and charity, Provide the statement of sources and uses of funds in the qard funds, The adoption of current value whenever it is possible. 
Meanwhile, the followings are the Corporate Governance indicator: 1) The board of directors has representative from Shariah board. 2) The terms of appointment of the non-executive directors are disclosed. 3) Directors' fees and remuneration (Directors remuneration is disclosed, Separate figures for salary and performance-related elements, and the basis on which performance is measured are be explained, Shareholder approve directors aggregate pay). 4) The company has nomination and renumeration committee. 5) Audit Committee (There is an audit committee, Audit committee include someone with expertise in accounting). 6) Shariah Supervisory Board (SSB meets with audit committee and/or external auditor to review financial statement, Details of the activities of SSB, the number of board meetings held in a year and details of attendance of each individual member in respect of meetings are disclosed, SSB is independent body). 7) Others ( There is a Risk Management Committee, English disclosure exists, There is a statement on Corporate Governance, The maintenance of an effective system of internal controls is disclosed, There is director's report ).

This study uses two control variables to test the hypothesis, first is type of Auditor. This study uses dummy variable as the measurement of type of auditor. The dummy variable of ' 1 ' is for company which used one of the big 4 auditor firms (Deloitte, Ernst and Young, KPMG, and PwC). Other than that, the company will has dummy variable of ' 0 ', the second control variable is Firm'sSize, This study uses natural logarithm of total assets as the measurement of firm's size.

\section{Results and Discussion}

The data indicated by the minimum and maximum values, the average (mean) and standard eviation of the research variables. The detailed sample can be seen in Table 1 and Table 2. Market Performance variable has the minimum value of 0,15 and maximum value of 5,01 from 136 samples. It means the wider range between these results will obtain the data that are distributed randomly. However, it shows the standard deviation 1,112 which is below the mean 1,557. As themarket performance is calculated by comparing the market value of equity and total debt to the book value of debt and assets, the mean result shows that listed companies in JII have a good market performance, most of companies have market value above $100 \%$ (155,70\%) better than their book value. Even the maximum value is 5,01 which is 3,46 above the average, then it means that there is one company has market value $501 \%$ better than its book value. In contrary, there is one company has market value only $15 \%$ than its book value which is $140,7 \%$ below the average.

Earnings Management variable has a small range with the minimum value of $-0,13$ and the maximum value of 0,37 from 136 samples. It also shows that standard deviation 0,103 is below the mean 0,120 . This result describes that the dispersion of data is clustered around the average value calculated, and it can be concluded that the sample and population have similarity. It means that data are homogeneous or the value of sample and population is distributed not randomly and it can be concluded that the sample does not have variation of data.

While the mean 0,12 indicates the high level of earnings management. Although there is no formal or legal regulation made by IAI or OJK about earnings management for Shariah-compliant companies but refer to the research done by Dunn and Mayhew (2000) and Mayangsari (2002) which determined that the upper limit is $15 \%$. Therefore we can conclude that on the average, earnings management done by listed companies in JII is so high, only $3 \%$ below the limit. While the minimum value is quite low, around $-13 \%$, around $28 \%$ below fromthe mean. On the other side, the maximum value reached out the upper limit, which is around $37 \%$.

Table 1. Descriptive Statistics

\begin{tabular}{|l|l|l|l|l|l|}
\hline & N & Minimum & Maximum & Mean & Deviation \\
\hline Market_Performance & 136 &, 15 & 5,01 & 1,5570 & 1,11201 \\
Earnings_Management & 136 &,- 13 &, 37 &, 1206 &, 10377 \\
Leverage & 136 &, 11 &, 45 &, 3997 &, 16681 \\
Disclosure & 136 &, 17 &, 45 &, 3600 &, 05959 \\
Firm_Size & 136 & 6,13 & 8,33 & 7,1638 &, 40069 \\
Valid N (listwise) & 136 & & & & \\
\hline
\end{tabular}

Source: Secondary data processed, 2014 
Table 2. Frequency Statistics

\begin{tabular}{|c|c|c|c|c|c|}
\hline & & Frequency & Percent & Valid Percent & $\begin{array}{l}\text { Cumulative } \\
\text { Percent }\end{array}$ \\
\hline \multirow[t]{3}{*}{ Valid } & Non Big 4 & 37 & 18,3 & 27,2 & 27,2 \\
\hline & Big 4 & 99 & 49,0 & 72,8 & 100,0 \\
\hline & Total & 136 & 67,3 & 100,0 & \\
\hline Missing & System & 66 & 32,7 & & \\
\hline Total & & 202 & 100,0 & & \\
\hline
\end{tabular}

Source: Secondary data processed, 2014

Leverage variable has a small range with the minimum value of 0,11 and the maximum value of 0,45 from 136 samples. It also shows that standard deviation 0,166 is below the mean 0,399 . This result describes that the dispersion of data is clustered around the average value calculated, and it can be concluded that the sample and population have similarity. It means that data are homogeneous or the value of sample and population is distributed not randomly and it can be concluded that the sample does not have variation ofdata.

While the mean $0,399(39,9 \%)$ gives a bad sign that reflects most companies listed in JII almost not categorized as the Shariah-compliant company since the OJK regulation requires Shariah-compliant company to have debt to asset ratio no more than $45 \%$. Even the maximum value reached the maximal requirement which is $45 \%$, and it is reached by several listed companies in the sample. While the minimum value is not so far below below the requirement, only around $29 \%$ lower, which is $16,6 \%$.

Disclosure variable has a small range with the minimum value of 0,17 and the maximum value of 0,45 from 136 samples. It also has a small range between the minimum value and the average value (mean) It also shows that standard deviation 0,059 is below the mean 0,360. This result describes that the dispersion of data is clustered around the average value calculated, and it can be concluded that the sample and population have similarity.

It means that data are homogeneous or the value of sample and population is distributed not randomly and it can be concluded that the sample does not have variation of data, it also shows in the range between the minimum value of data is 0,17 and maximum data is 0,45 is small. While the mean 0,360 gives a bad sign reflecting that the listed companies have a low level (36\% of $100 \%)$ of disclosure particularly on islamicity and corporate governance indices as regulated by AAOIFI standards. Even the maximum value is only $6 \%$ above the mean, $45 \%$, which is not more than $50 \%$. While the minimum value is $19 \%$ below the mean, $17 \%$, which is so low level of disclosure.

Firm size as the control variable has the minimum value of 6,13 and the maximum value of 8,33 from 136 samples. It has the mean 7,163 and standard deviation 0,400. This result describes that the dispersion of data is clustered around the average value calculated, and it can be concluded that the sample and population havesimilarity.

It means that data are homogeneous or the value of sample and population is distributed not randomly and it can be concluded that the sample does not have variation of data, it also shows in the range between the minimum value of data is 6,13 and maximum data is 8,33 which is so small. Since the smallest companies in this sample research has 6,13 point while the biggest companies in this sample research has 8,33 ; therefore we can conclude that most companies on this sample research are the medium since the mean is 7,163 . It only has around 1 point difference compared to both minimum and maximum value.

From the type of auditor variable result, we can conclude that majority of sample research, around $72,8 \%$ (99 companies), hired one of the big 4 auditor firms (Ernst \& Young, Deloitte, KPMG, and PwC) as their external auditor. While the remaining 27,2\% (37 companies) hired the non-big 4 auditor firm.

Regression equation above shows that the earnings management (EM) and type of auditor (Aud) have positive coefficient. Meanwhile the leverage (LEV), corporate disclosure (CD), and firm size (FS) have negative coefficient. Based on this regression equation, it can be interpreted that: Earnings management has positive regression coefficient or slope (B) value of $+4,083$. It means the more earnings management run by the company, the market performance would be better. On contrast, leverage ratio (LEV) has negative regression coefficient or slope (B) value of -1.996 , it means the higher company's debt would result in a worse market 
performance of the company. While the corporate disclosure ratio (CD) has negative regression coefficient or slope (B) value of $-0,238$, it means that the more components disclosed by the company will lead to the worse market performance.

Table 3. Multiple Regression Analysis

a.Dependent Variable:Market_Performance

\begin{tabular}{|c|c|c|c|c|c|}
\hline & \multicolumn{2}{|c|}{$\begin{array}{l}\text { Unstandardized } \\
\text { Coefficients }\end{array}$} & \multicolumn{3}{|c|}{$\begin{array}{l}\text { Standardized } \\
\text { Coefficients }\end{array}$} \\
\hline Mode1 & B & Std. Error & Beta & $\mathrm{t}$ & Sig. \\
\hline (Constant) & 5,865 & 1,297 & & 4,521 & 0,000 \\
\hline $\begin{array}{l}\text { Earnings_Management } \\
\text { Leverage }\end{array}$ & 4,083 & 0,764 & 0,381 & 5,346 & 0,000 \\
\hline Disclosure Firm_Size Type of & $-1,996$ & 0,511 & $-0,299$ & $-3,906$ & 0,000 \\
\hline Auditor & $-0,238$ & 1,274 & $-0,013$ & $-0,187$ & 0,852 \\
\hline & $-0,585$ & 0,203 & $-0,211$ & $-2,887$ & 0,005 \\
\hline & 0,376 & 0,188 &, 151 & 2,006 & ,047 \\
\hline
\end{tabular}

As the control variable, firm size ratio (SIZE) has negative regression coefficient or slope (B) value of 0,585 . It means the bigger size of the company will lead to the lower level of company's market performance. On the other hand, the type of auditor (AUD) has positive regression coefficient or slope (B) value of 0,376 . It means the use of one of big 4 auditor firm will result in better market performance of company.

The result of multiple regression analysis on hypothesis 1 shows that the earnings management has significant effect on the market performance. The coefficient of EM is positive $(+4,083)$ and statistically significant $(\mathrm{p}=0.000)$, it means the hypothesis 1 is accepted. The result shows that Shariah-compliant companies which have low indications of earnings management will result in a good market performance. This result is in line with the previous study conducted by Al Fayoumi et al (2010) in Isa, Sanusi, Suffian, \& Omar (2013), which shows that earnings management has positive and significant impact to the market performance.

Table 4. Summary of Hypothesis Testing

\begin{tabular}{lllrcl}
\hline H. No. & Var. & Hypothesis & $\begin{array}{r}\text { Result } \\
\text { Sig. }\end{array}$ & B & Decision \\
\hline H1 & EM & $\begin{array}{l}\text { EM has positive impact to the } \\
\text { market performance }\end{array}$ & 0.000 & 4,083 & Accepted \\
H2 & LEV & $\begin{array}{l}\text { LEV has negative impact } \\
\text { to the market performance }\end{array}$ & 0.000 & -1.996 & Accepted \\
H3 & CD & $\begin{array}{l}\text { CD has positive impact to } \\
\text { the market performance }\end{array}$ & 0.852 & -0.238 & Rejected \\
\hline
\end{tabular}

Source: Secondary data processed, 2014

Although earnings management adds value to the market performance, but Shariah-compliant companies should avoid it due to the lack of Islamic value inside the earnings management practices. Islamic value is based on the two major sources; Qur'an and Sunna. Islam does leave no room for ambigous interpretation and individuals are supposed to adhere to the ethical system that Islam presents. It has been narrated in one of the Hadith of Prophet Muhammad SAW, "A honest business manwill be amongs the Prophets, the truthful and the martyrs on the day of judgment" (Narated by Tirmidzi). Therefore the Shariah-compliant companies must report their financial condition as it is.

On the other side, the result of multiple regression analysis on hypothesis 2 shows that the leverage ratio has significant effect on the market performance. The coefficient of EM is negative $(-1,996)$ and statistically significant $(p=0.000)$, it means the hypothesis 2 is accepted. The result shows that Shariah-compliant companies have a medium level of debt to assets ratio, and the greater number of debts will lead to the worse market performance. It is in line with the fundamental Shariahhpriciple which prohibit riba, because the core belief in Islamic finance is that money should not in itself be an earning asset. In Islam, money is only permissible as the exchange instrument and transactional purposes. 
The result of research hopefully can encourage Shariah-compliant companies to not have debts since Islam commands us to refrain from charging interest and to share financial risk, thereby mudharabah or musyarakah financing can be the best alternative. This result is also in line with the previous study conducted by Datta et al (2000) in Isa et al (2013), which shows that leverage ratio has negative and significant impact to the market performance.

Meanwhile the result of multiple regression analysis on hypothesis 3 shows that the corporate disclosure index has significant effect on the market performance. The coefficient of EM is negative $(-0,238)$ and statistically not significant $(\mathrm{p}=0,852)$, it means the hypothesis 3 is rejected. It is due to the fact that the indicators used in this study are corporate governance and Shariah compliance indicators as regulated by AAOIFI standard. However, most companies have not fulfilled those indicators yet.

One of the reason is because many points of the indicators are not being adopted by the regulation in Indonesia. Therefore it resulted in almost similarpercentage of corporate disclosure index among those companies and investors do not give much attention on the Islamicity of corporate disclosure even for the Shariah-compliant companies. That is why the result of this study shows that corporate disclosure has negative and insignificant impact to the market performance. This result is different from the results of research conducted by Lev, Petrovits, and Radhakrishnan (2009) in Ibrahim (2004) which stated that the corporate disclosure has positive and significant effect on the market performance.

\section{Conclusion}

After conducting some analysis for certain analytical methods such as descriptive analysis, classical assumption test, and hypothesis testing on sample data of listed companies in Jakarta Islamic Index, the researcher will present the conclusion of this research. This result is based on the annual report Islamic banks published by Bank Indonesia during 2010 to 2013. Based on the statistical test, analysis, and discussion that have been done in the previous chapter, it can be concluded that:Earnings management has positive effect to the market performance. It is a necessity that needs to be fixed by companies. Although earnings management adds value to the market performance, but Shariah-compliant companies should avoid it due to the lack of Islamic value inside the earnings managementpractices. The leverage has negative effect to the market performance. It is in line with the fundamental Shariahpriciple which prohibit riba, because the core belief in Islamic finance is that money should not in itself be an earning asset. As the best alternative, Islam providemudharabah and musyarakah financing to fulfill the company's financial need.Corporate disclosure index has insigificant negative effect of to the marketperformance.

The result of this study proves empirically that earnings management practices in Shariah-compliant companies can improve their market performance. It is a necessity that needs to be fixed by companies. Although the earnings management is done in a way that does not deviate with the regulations set by IAI, but the information generated from the financial statements contain elements of earnings management which can mislead users in making decision. Moreover earnings management does not comply with Shariah principles as well as having debt. Furthermore, the result of this study proves that the debts have negative effect to the market performance. It should encourage company to reduce the debts which have riba and no risk-sharing, then turn to have the better one, mudharabah and musyarakah financing.In this study there are some limitations that researcher get in conducted this research. First, this research used only three independent variables which are able to explain its influence to marketperformance. Second, the index used for Islamicity disclosure is not familiar to the Sharia- compliant companies in Indonesia.

From the research that has been done, then the researcher give an recommendation for further research as follows: Future studies should add others variable which has significant influence to the market performance, such as good corporate governance (GCG), corporate social responsibility (CSR) and others. In addition, future studies will be better when using another Islamicity disclosure index to be the proxy of corporate disclosure in order to have a significant effect to the market performance.

\section{References}

AAOIFI.(2002). Accounting and Auditing, Governance Standards for Islamic Financial Institutions. Manama: Accounting and Auditing Organization for Islamic Financial Institutions.

Adiwitarsa, R. (2011). Pengaruh Rasio Camel terhadap Praktik Manajemen Laba pada Bank Umum Syariah di Indonesia, Skripsi Program S1, Universitas Pembangunan Nasional "Veteran”, Jawa Timur.

Alhabshi, S. O. (1994). Development of Capital Market under Islamic Principles. Paper presented at the Conference on Managing and Implementing Interest Free Banking/Islamic Financial System. Link: https://kantakji.com/media/8184/y102.pdf 
Choong, Y. V, Thim, C.K, Kyzy, B.T. (2012). Performance of Islamic Commercial Banks in Malaysia: An Empirical Study. Journal of Islamic Economics, Banking and Finance, 8(2), 67-80..

Datta, S., Iskandar-Datta, M., and Patel A. (2000). Some Evidence on the Uniqueness of Initial Public Debt Offerings. Journal of Finance, 55(2). 715-743

Dunn, K., \& Mayhew, B. (2004). Auditor Industry Specialization and Client Disclosure Quality. Review of Accounting Studies, 9: 35-58

Ibrahim S.H.M, Wirman, A, Alrazi, B \& Nor, M.N.M \& Pramono, S (2004). Alternative Disclosure and Performance Measures For Islamic Banks. IIUM, Malaysia, 1-37

Indriyani, Y. (2010). Pengaruh Kualitas Auditor, Coorporate Governance, Leverage, dan Kinerja Keuangan terhadap Manajemen Laba. Skripsi Program S1, Universitas Diponegoro, Semarang

Isa, Y. M., Sanusi, Z. M., Suffian, M. T., \& Omar, N. B. (2013).Measuring Market Performance of ShariahCompliant Companies: The Relevance of Earnings Management and Leverage.

Lev, B., Petrovits, C., \& Radhakrishnan, S. (2010). Is Doing Good Good for You? How Corporate Charitable Contributions Enhance Revenue Growth. Strategic Management Journal Strat. 31: 182-200

Martani, D, Mulyono \& Khairurizka, R. (2009).The effect of financial ratios, firm size, and cash flow from operating activities in the interim report to the stock return.Chinese Business Review. 8(6), 44-45

Mayangsari, Sekar. (2004). Bukti Empiris Pengaruh Spesialisasi Industri Auditor Terhadap Earnings Response Coefficient. Jurnal Riset Akuntansi Indonesia, 7(2), pp.154-178

Hillier, D.. Ross, S.A., Wesetrfield, R.W., Jaffe, J., \& Jordan, B.D. (2008). Corporate Finance, British, UK: MacGraw-Hill

Rahman, M., Moniruzzaman, M., and Sharif, J. (2013). Techniques, motives and controls of earnings management. International Journal of Information Technology and Business Management, 11(1), 22-24.

Susanto, A. (2010). Indikasi Praktek Pengelolaan Laba dan Faktor-faktor yang Mempengaruhinya (Studi Empiris pada Sektor Perbankan sebelum Krisis Perbankan Nasional), Tesis Program Magister Akuntansi, Universitas Indonesia, Jakarta

Zunaidah, S. \& Nor, F. M. (2008). Dividends, Ownership Structure and Board Governance on Firm Value: Empirical Evidence from Malaysian Listed Firms. Malaysian Accounting Review, 7(2), 55-94. 